\title{
IF 鋼の延性に及ぼすひずみ速度および温度の影響
}

\author{
津山 青史*・角田 浩之*・細谷 佳弘*
}

Effects of Strain Rate and Temperature on Ductility of Interstitial Free Steel Sheet

Seishi Tsuyama, Hiroyuki Tsunoda and Yoshihiro Hosoya

Synopsis : Effects of strain rate and temperature on tensile ductility of an interstitial free ultra low carbon steel sheet, which does not show dynamic strain aging have been studied. Total elongation of this steel decreases with an increase in strain rate up to $5 \times 10^{-2} / \mathrm{s}$ and contrarily increases in the higher strain rate region. This increase of total elongation is due to a drastic increase of post-uniform elongation, which can be explained neither by heat generation due to plastic deformation nor by equivalency of temperature to strain rate. The possible mechanism for large post-uniform elongation in the high strain rate region is an increase in diffusion of local necking area due to grain boundary sliding.

Key words : ultra low carbon steel; interstitial free steel; plastic deformation; ductility; grain boundary sliding; strain rate; temperature.

\section{1. 緒言}

プレス成形のように鋼板に高速で変形を与える場合，鋼 板の成形性, とくに延性は, 変形時のひずみ速度および変 形に伴う温度上昇に大きく影響されると考えられる。この ような観点から，低炭素鋼や極低炭素鋼の延性に及ぼす温 度およびひずみ速度の影響1) 3)が固溶炭素 (C) および窒素 （N）による青熱脆性と関連づけて検討されている。一方， 極低炭素鋼にNbあるいはTiなどの炭窒化物形成元素を添加 して固溶CおよびNを固定した，いわゆるIF (Interstitial Free）鋼は，プレス成形用鋼板として工業的に広く使われ てきているにもかかわらず，温度やひずみ速度による延性 の変化挙動について検討された例は少ない。固溶CおよびN を含まないIF鋼に関しては, 大上 $5^{4)}$ が, 温度上昇とともに 強度, 延性が低下すること, 広瀬 $5^{5}$ が，ひずみ速度 $10^{-4}$ $\sim 10^{-1} \mathrm{~s}^{-1}$ の範囲でひずみ速度の増加にともない強度が上昇 し，延性が低下することを報告しているにすぎない。しか し, 実際のプレス成形時における鋼板のひずみ速度は $10^{1} \mathrm{~s}^{-1}$ 程度であり，プレス成形相当のひずみ速度を与えた場合に おけるIF鋼の延性に関する知見は従来にない。

そこで本報告では，プレス成形相当のひずみ速度下にお いてひずみ速度および加工発熱が延性に及ぼす影響を明ら かにすることを主眼として，IF鋼の延性に及ぼす温度，ひ ずみ速度の影響について調査した結果を述べる。またひ ずみ速度による延性の変化について, 微視組織変化の観点 から検討を加えた。

\section{2. 供試鋼および実験方法}

延性に対する固溶CおよびNによる青熱脆性現象を排除す るため, 鋼中CおよびN量に対して過剩のTiおよびNbを添 加した実機製造による板厚 $0.8 \mathrm{~mm}$ の極低炭素冷延鋼板（連 続焼鈍材) を供試鋼とした。化学成分をTable 1 に示す。供 試鋼中の固溶C, Nを内部摩擦法で測定した結果, Snoekピ 一クは検出されなかった。なお，ミク口組織は粒度番号で 6.5 のポリゴナルフェライト単相組織を呈する。

この冷延鋼板から, 後述する目的に応じて, Table 2 に示 す 3 種類の試験片を採取し，ひずみ速度および試験温度を 変化させ引張試験を実施した。

まず，1の試験においては，JIS 5 号試験片を用い室温に おける引張特性に及ぼすひずみ速度の影響を明らかにする

Table 1. Chemical composition of steel tested (mass\%).

\begin{tabular}{c|c|c|c|c|c|c|c|c|c}
\hline $\mathrm{C}$ & $\mathrm{Si}$ & $\mathrm{Mn}$ & $\mathrm{P}$ & $\mathrm{S}$ & sol.Al & $\mathrm{N}$ & $\mathrm{Nb}$ & $\mathrm{Ti}$ & $\mathrm{Ti}^{*} / \mathrm{C}$ \\
\hline 0.0021 & 0.02 & 0.15 & 0.004 & 0.002 & 0.046 & 0.0020 & 0.009 & 0.083 & 8.71 \\
\hline
\end{tabular}

Table 2. Specimen size and condition of tensile test.

\begin{tabular}{c|c|c|c}
\hline & $\begin{array}{c}\text { Specimen size } \\
(\mathrm{mm})\end{array}$ & $\begin{array}{c}\text { Strain rate } \\
\left(\mathrm{s}^{-1}\right)\end{array}$ & $\begin{array}{c}\text { Test temperature } \\
\left({ }^{\circ} \mathrm{C}\right)\end{array}$ \\
\hline 1 & $25 \mathrm{w} \times 50 \mathrm{GL}$ & $1.4 \times 10^{-4}-1.4 \times 10^{1}$ & Room temperature \\
2 & $12.5 \mathrm{w} \times 25 \mathrm{GL}$ & $1.4 \times 10^{-3}$ & $20-300$ \\
3 & $6.25 \mathrm{w} \times 25 \mathrm{GL}$ & $1.4 \times 10^{-3}, 1.4 \times 10^{1}$ & $20,-100$ \\
\hline
\end{tabular}


ことを目的とした。つぎに，2の試験においては，ひずみ 速度を一定とし，温度の影響を明らかにすることを目的と した。試験片の大きさを室温引張の場合の半分としたのは, 試験片の温度分布の均一性を考虑したためである。試験片 の加熱には赤外線式加熱炉を用い, 3 min均熱することによ り平行部の温度偏差を $\pm 2{ }^{\circ} \mathrm{C}$ 以下とした後, 引張を開始し た。また， 3 の試験においては, 温度とひずみ速度の等価 性を比較することを目的とした。

ここで，本報告におけるひずみ速度とは，試験片の平行 部長さとクロスヘッド速度から計算で求めた值である。な お，試験片の長手方向はいずれも圧延方向に平行とし，ひ ずみ速度 $1.4 \times 10^{-4} \sim 1.4 \times 10^{-1} \mathrm{~s}^{-1}$ の場合はインストロン型引 張試験機を，ひずみ速度 $1.4 \times 10^{-1} \sim 1.4 \times 10^{1} \mathrm{~s}^{-1}$ の場合は油 圧式高速引張試験機を用いた。ここで，今回採用した試験 片のように平行部長さに対し平行部幅が大きい場合は，肩 部の拘束によって必ずしも一様に変形しないため，便宜的 に一様伸びとして引張試験時の最高荷重点までの伸びを， 局部伸びとして全伸びから一様伸びを差し引いたものを用 いた。

また，ひずみ速度 $10^{-3} \mathrm{~s}^{-1}$ と $10^{1} \mathrm{~s}^{-1}$ の引張試験については， 10\%の引張予ひずみを与えた後に透過型電子顕微鏡によっ て下部組織を観察するとともに，あらかじめけがき線を入 れた試験片を破断まで引張り，試験片の各位置におけるけ がき線の様子を走査型電子顕微鏡で観察した。

\section{3. 結果}

\section{$3 ・ 1$ 室温引張における延性に及ぼすひずみ速度の影響}

Fig. 1 に，ひずみ速度 $10^{-4} \sim 10^{1} \mathrm{~s}^{-1}$ の範囲における室温引 張試験による全伸び，一様伸びおよび局部伸びならびに引 張強度の変化を示す。ひずみ速度 $10^{-4} \sim 10^{0} \mathrm{~s}^{-1}$ の範囲では， ひずみ速度の増加に伴って一様伸びは減少していく。一方, 局部伸びはひずみ速度 $10^{-4} \sim 5 \times 10^{-2} \mathrm{~s}^{-1}$ の範囲ではひずみ速 度によってほとんど变化しないのに対し,ひずみ速度が $5 \times$ $10^{-2} \mathrm{~S}^{-1}$ を超えると急激に増加する。このようなひずみ速度 による一様伸びと局部伸びの変化により, 全伸びは $5 \times 10^{-2}$ $\mathrm{s}^{-1}$ 近傍で極小值となる。引張強度は，ひずみ速度の増加に 伴って単調に増加する。なお, 降伏強度は, 読み取り精度 上信頼できる範囲として，10-1 $\mathrm{s}^{-1}$ 以下についてプロットし た。

ひずみ速度が $10^{-4} \sim 10^{-1} \mathrm{~S}^{-1}$ の範囲について,一様伸びと相 関があるとされる加工硬化指数 (n值) の変化を応力・ひず み曲線から計算した結果をFig. 2 に示す。ひずみ速度が増加 するにつれてn值のレベルは低下しており，とくに高ひずみ 域でのn值に明瞭な差があることがわかる。また，ひずみ速 度 $10^{-1} \mathrm{~s}^{-1}$ の場合は, 低ひずみ速度の場合と比べてn值の立ち 上がりがかなり遅れている。すなわち，ひずみ速度の増加 に伴って一様伸びが減少していく現象は, ひずみ速度の増

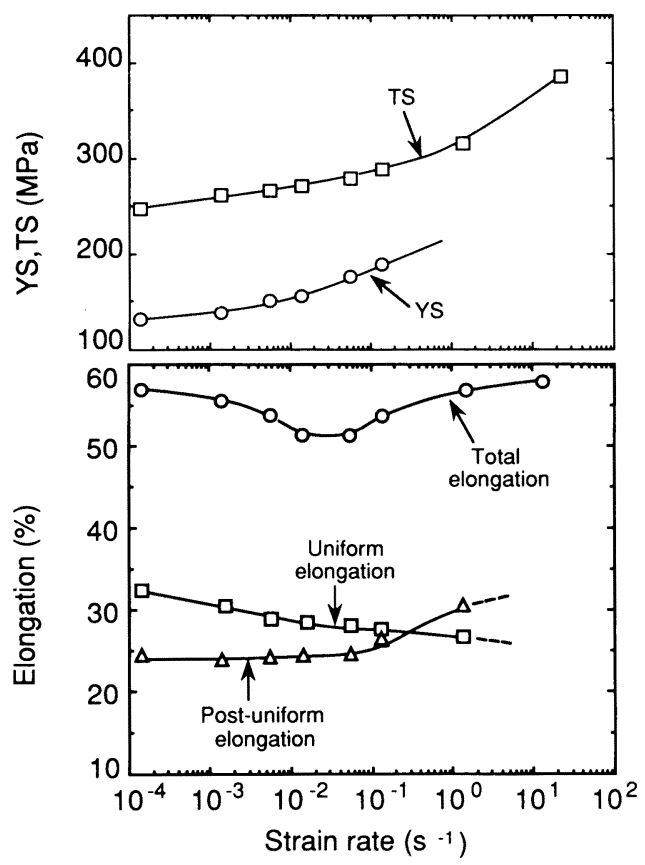

Fig. 1. Effect of strain rate on strength and elongation.

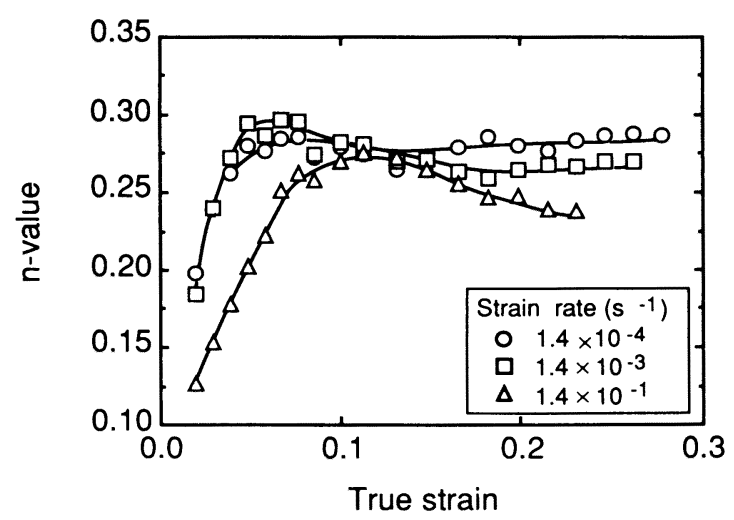

Fig. 2. Change in strain dependence of n-value with strain rate at room temperature.

加に伴うn值の低下に対応しているといえる。

\section{$3 \cdot 2$ 延性に及ぼす試験温度および加工発熱の影響}

Fig. 3 に, ひずみ速度 $10^{-3} \sim 10^{-1} \mathrm{~s}^{-1}$ の範囲において, 破断 部近傍における引張過程での温度上昇を熱電対により測定 した結果を示す。横軸は板厚および板幅減少から求めた真 ひずみを対数で示している。また，断熱変形を仮定して次 式6を用いて計算により求めた温度上昇をあわせて示してい る。

$\Delta \mathrm{T}=\mathrm{Ak}_{\mathrm{m}} \epsilon /(\mathrm{C} \rho)$

ここで, $\Delta \mathrm{T}$ : 温度上昇 $\left({ }^{\circ} \mathrm{C}\right), \mathrm{A}$ ：仕事の熱当量 $(1 / 427$ $\mathrm{kcal} / \mathrm{kg} \cdot \mathrm{m}$ )

$\mathrm{k}_{\mathrm{m}}$ : 変形中の平均変形抵抗 $\left(\mathrm{kg} / \mathrm{m}^{2}\right), \boldsymbol{\epsilon}:$ ひずみ, $\mathrm{C}:$ 比 熱 $\left(\mathrm{kcal} / \mathrm{kg} \cdot{ }^{\circ} \mathrm{C}\right), \rho$ : 密度 $\left(\mathrm{kg} / \mathrm{m}^{3}\right)$

なお，比熱については、その温度依存性が小さいとして， 


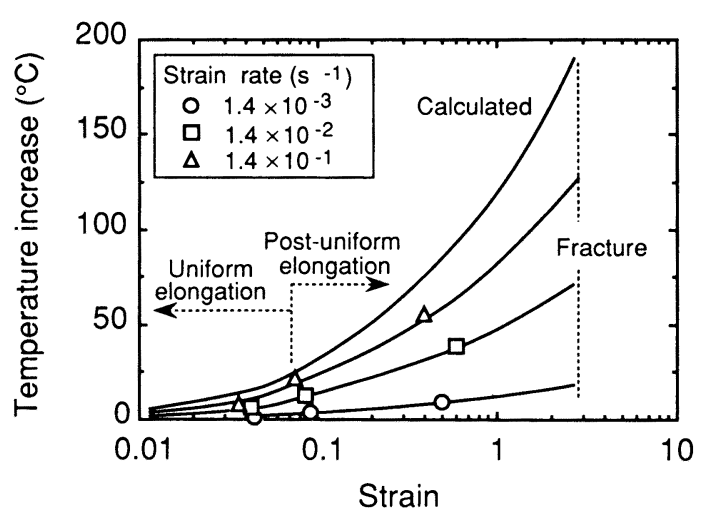

Fig. 3. Effects of strain and strain rate on temperature increase during tensile deformation.

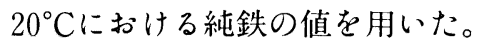

ここで，破断部近傍では，引張によるひずみは，ほぼ板 厚ひずみと等しくなり, 真の破断部分においては板厚がゼ 口になるため, 計算上での温度上昇は無限大となる。しか しながら，マクロ的な全伸びに対してこのような極微小部 分における温度上昇はほとんど影響しないと考えられるた め, $50 \mu \mathrm{m}$ まで板厚が減少したときに破断に至ると仮定した。 この $50 \mu \mathrm{m}$ というは, 破断部を投影機レベルで観察したと きのマクロ的な破断部板厚に相当する。Fig. 3 より,ひずみ 速度がかなり大きい場合においても，一様伸び限界での温 度上昇は $20^{\circ} \mathrm{C}$ 程度であり, 破断部分のごく近傍における温 度上昇も $200^{\circ} \mathrm{C}$ 以下, 比熱の温度依存性を考虑すれば $170^{\circ} \mathrm{C}$ 以下であるといえる。

Fig. 4 に, 試験温度 $20 \sim 300^{\circ} \mathrm{C}$ 範囲における, 全伸び, 一様伸びょよび局部伸びの変化を示す。ひずみ速度は $10^{-3} \mathrm{~s}^{-1}$ と小さいことから，ひずみの進行に伴う温度上昇はほとん ぞ無視できると考えられる。20３00 $\mathrm{C}$ の試験温度範囲にお いては, 温度が上昇するにつれて一様伸びは単調に減少す るのに対し, 局部伸びはほとんど変化しない。したがって, 室温引張においてひずみ速度が $5 \times 10^{-2} \mathrm{~S}^{-1}$ を超えた場合に 局部伸びの増加によって全伸びが増加する挙動は, 試験片 の温度上昇からは説明できないことになる。

また，一様伸びが変化することに関しても，一様伸び限

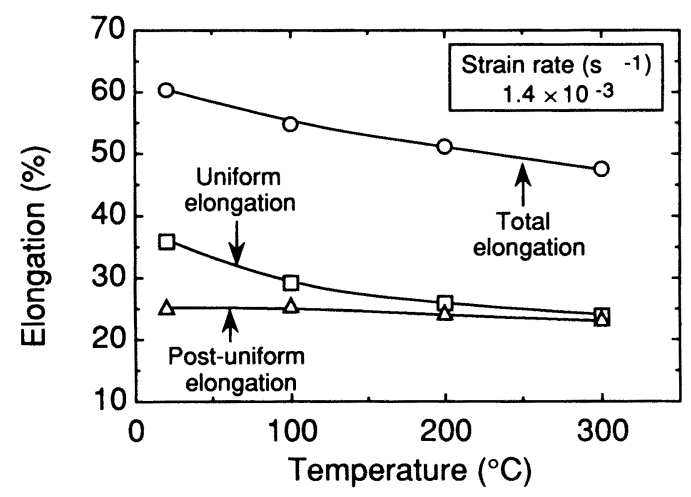

Fig. 4. Effect of test temperature on elongation.
Table 3. Effects of strain rate and temperature on tensile strength and elongation.

\begin{tabular}{c|c|r|c|c|c|c}
\hline $\begin{array}{c}\text { Number } \\
\text { of } \\
\text { condition }\end{array}$ & $\begin{array}{c}\text { Strain rate } \\
\left(\mathrm{s}^{-1}\right)\end{array}$ & $\begin{array}{c}\text { Temperature } \\
\left({ }^{\circ} \mathrm{C}\right)\end{array}$ & $\begin{array}{c}\text { Tensile } \\
\text { strength } \\
(\mathrm{MPa})\end{array}$ & $\begin{array}{c}\text { Total } \\
\text { elongation } \\
(\%)\end{array}$ & $\begin{array}{c}\text { Uniform } \\
\text { elongation } \\
(\%)\end{array}$ & $\begin{array}{c}\text { Post-uniform } \\
\text { elongation } \\
(\%)\end{array}$ \\
\hline 1 & $1.4 \times 10^{-3}$ & 20 & 261 & 50.6 & 29.3 & 21.3 \\
2 & $1.4 \times 10^{1}$ & 20 & 381 & 55.9 & 26.6 & 29.3 \\
3 & $1.4 \times 10^{-3}$ & -100 & 399 & 34.2 & 18.4 & 15.8 \\
\hline
\end{tabular}

界時の温度上昇が高々 $20^{\circ} \mathrm{C}$ 程度であり，その温度上昇によ る一様伸びの低下はごくわずかであるため, やはり, 温度 上昇の点からは十分に説明することができない。すなわち， 室温引張時のひずみ速度の増加による一様伸びの減少 と, 局部伸びの増加は，ひずみ速度そのものの効果によると考 えられる。

\section{$3 \cdot 3$ ひずみ速度と試験温度の等価性に関する検討}

金属材料の变形挙動においては, 一般に高ひずみ速度側 での現象が低温側での現象と等価であることが知られてい る。IF鋼の延性に関してもこのことがあてはまるかどうか を確認するため, 同一サイズの試験片を用いて, 高ひずみ 速度もしくは低温での引張試験を行った。試験条件と結果 をTable 3 に示す。なお, 試験条件 1 は低ひずみ速度で室温 の場合, 試験条件 2 は高ひずみ速度で室温の場合, 試験条 件 3 は低ひずみ速度で低温の場合に対応する。

試験条件 2 と 3 での引張強度がおよそ等しいことから， $10^{1} \mathrm{~s}^{-1}$ というひずみ速度とー $100 \mathrm{C}^{\circ}$ とう試験温度は変形抵 抗に対してはほぼ等価であるといえる。しかし, 局部伸び については高ひずみ速度側で増加しているのとは対照的に 低温側で減少しており，変形抵抗にみられるようなひずみ 速度と温度の等価性は, 局部伸びに対しては成り立たない。

\section{4. 考察}

以上の結果から, IF鋼の室温引張においてはひずみ速度 が増加すると一様伸びが減少し, 局部伸びが増加すること, またこの現象は加工発熱によるものではないこと，さらに 局部伸びの変化はひずみ速度と温度の等価性では説明でき ないことがわかった。そこで，IF鋼の延性に及ぼすひずみ 速度の影響について, 微視組織変化の観点から考察を行っ た。

\section{4 ・1 一様伸びの変化に及ぼすひずみ速度の影響}

Fig. 2 に示したように，ひずみ速度が増加するとn值の立 ち上がりが遅れ，n値のレベルが低下する。このことから， ひずみ速度の増加による転位の形態や密度の変化が予想さ れる。下部組織の観察結果をFig. 5 に示す。ひずみ速度 $10^{1}$ $\mathrm{s}^{-1}$ の場合は, ひずみ速度 $10^{-3} \mathrm{~s}^{-1} に$ 比べて転位が不均一に分 布する傾向が強く, 全体的に転位密度は低くなっている。 また，ひずみ速度 $10^{-3} \mathrm{~s}^{-1}$ の場合には加工セル組織7)がすでに 形成されているのに対して,ひずみ速度 $10^{1} \mathrm{~s}^{-1}$ の場合は加工 

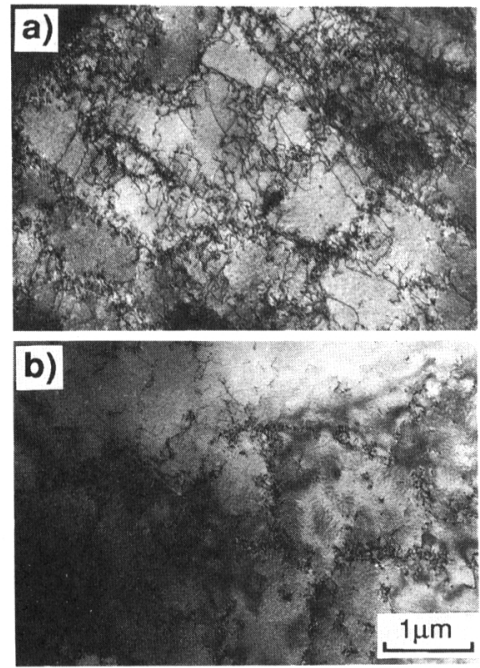

Fig. 5. Transmission electron micrographs showing the morphological change of dislocation with different strain rate of a) $1.4 \times 10^{-3}$ and b) 1.4 $\times 10^{1} / \mathrm{s}^{-1}$ (tensile strain : 0.1 ).

セル組織を形成しはじめる段階にある。

すなわち，ひずみ速度が増加すると転位が増殖しにくく なることにより，加工セル組織を形成する段階が遅れるも のと考えられる。この結果, 変形に伴う真応力の増加に対 して材料の加工硬化が追いつかなくなり，低ひずみ速度の 場合に比べて早期にくびれを生じ，一様伸びが減少したも のと考えられる。

\section{$4 \cdot 2$ 局部伸びの変化に及ぼすひずみ速度の影響}

局部伸びは極限変形能とくびれの拡散性に支配される ここで，ひずみ速度が $5 \times 10^{-2} \mathrm{~S}^{-1}$ を超えると局部伸びが急 激に増加する現象について，極限変形能とくびれの拡散性 のいずれが支配的であるかね明らかにするため，試験片の 幅および板厚ひずみの分布を測定した。Fig. 6 に示すように, ひずみ速度 $5 \times 10^{-2} \mathrm{~s}^{-1}$ の場合には，低ひずみ速度の場合に 比べて板幅，板厚ひずみが全体的に小さくなっている。こ れは，低ひずみ速度の場合よりも一様変形能が小さくなっ ていることによる。一方，さらにひずみ速度が大きい場合 には，破断部分からかなり離れた場所でも板幅，板厚ひず みが増加しており，とくに板厚ひずみの増加が著しい。こ れは，高ひずみ速度においては板厚くびれがかなりの領域 まで拡散したこと意味する。極限変形能はひずみ速度に よってほとんど変わらないことから，ひずみ速度の増加に よる局部伸びの上昇はくびれの拡散性によって支配されて いるといえる。

3 ・ 3 節で，局部伸びの変化に対してはひずみ速度と温 度の等価性がないことを述べたが，このことは，ひずみ速 度による局部伸びの変化は，一様伸びの変化のように転位 論的に説明できるものではないことを意味している。すな わち，ひずみ速度が $5 \times 10^{-2} \mathrm{~s}^{-1}$ を超える範囲で局部伸びが 急激に増加することは，このひずみ速度域では局部変形に

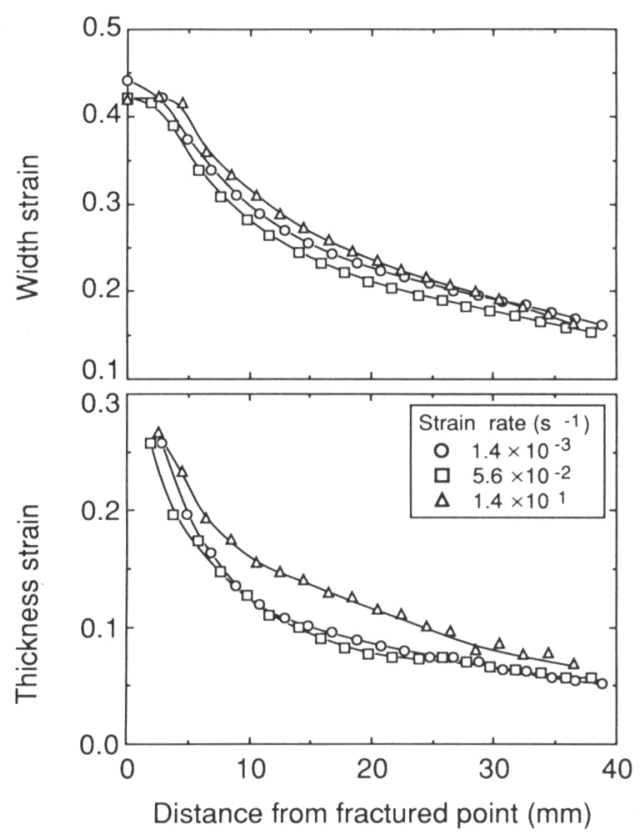

Fig. 6. Change in strain distributions of width and thickness with strain rate.

対して転位の運動以外の別の変形メカニズムが作用してい ることを示唆している。

超塑性材料に限らず一般の鉄鋼材料においても，クリ一 プ現象には粒界すべりが関与していることが知られている9 IF鋼では侵入型固溶元素が固定されていることにより粒界 が純化されているため, 通常の鉄鋼材料では起こりにくい ような条件下においても粒界すべりが起こる可能性が考え られる。そこで，けがき線を入れた試験片を破断させた後 に走査型電子顕微鏡で観察することにより，その検証を行

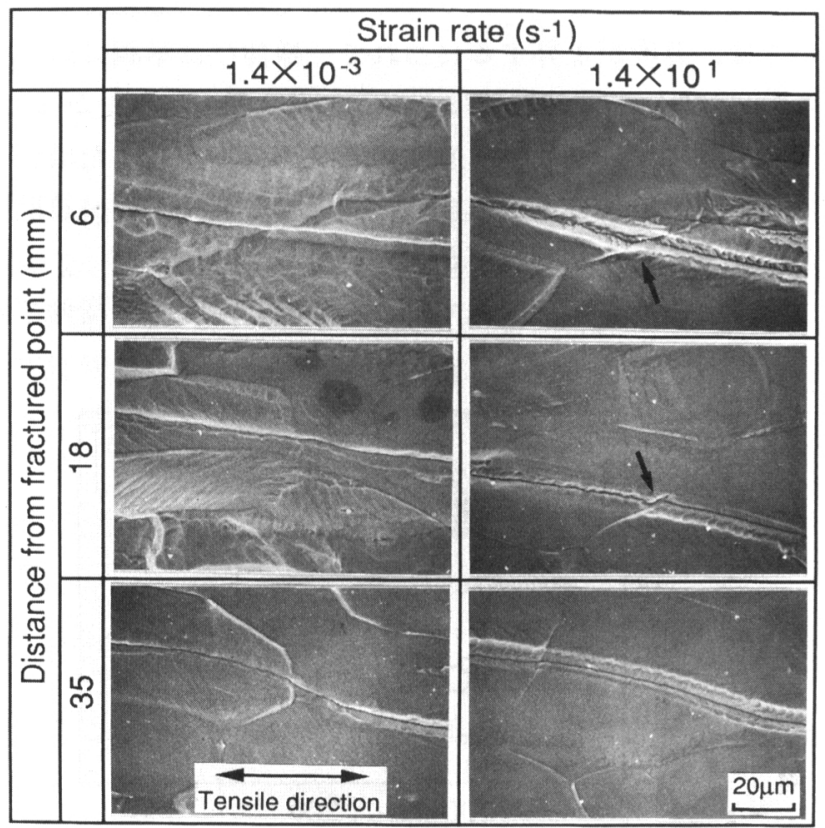

Fig. 7. Surface appearances of tensile specimens with scratched line after deformation. Arrow mark indicates an evidence of grain boundary sliding. 
った。

破断部から 6 35mmの範囲で観察したけがき線の状態を Fig. 7 に示す。写真から明らかなように,ひずみ速度 $10^{-3} \mathrm{~s}^{-1}$ の場合にはいずれの位置においてもけがき線は連続した線 として観察された。これに対して，ひずみ速度 $10^{1} \mathrm{~s}^{-1}$ の場合 には破断部からの距離が $30 \mathrm{~mm}$ 以内の範囲でけがき線のずれ が観察された。このずれは結晶粒界が引張方向に对して $45^{\circ}$ に近い方向になっている場所で多くみられたが，一部は $90^{\circ}$ 方向の場合にもみられたことから，結晶粒が最大せん断応 力方向に横す心゙りするか，もしくは回転することによって 粒界す心゙りが生じているものと考えられる。ここで粒界す ベりが観察された領域は, Fig. 6 に示した板厚くびれが拡散 している領域に対応している。これは，最もくびれの進行 している領域から周囲の領域へと粒界す心゙りが順次発生す ることによって，板厚くびれが拡散していくことを示唆し ている。すなわち，ひずみ速度が $5 \times 10^{-2} \mathrm{~S}^{-1}$ を超えたあた りから，局部变形域において粒界すべりが発生することに よりくびれの拡散性が高まり，局部伸びが大きくなるもの と思われる。

\section{5. 結論}

IF鋼の延性に及洔す温度, ひずみ速度の影響について検 討した結果をまとめると，以下のとおりである。
（1）ひずみ速度が $10^{-4} \sim 10^{1} \mathrm{~s}^{-1}$ の範囲で増加するにつれて 一様伸びは減少する。一方，ひずみ速度が $5 \times 10^{-2} \mathrm{~s}^{-1}$ を超 えると局部伸びは急激に増加する。この結果, 全伸びは $5 \times$ $10^{-2} \mathrm{~s}^{-1}$ 近傍で極小值となる。

（2）.このような延性の変化は, 加工発熱およびひずみ速 度と温度の等価性だけでは説明できない。

(3) 汹ずみ速度の増加に伴って一様伸びか減少するのは, ひずみ速度が増加すると転位が増殖しにくくなることによ り，加工硬化が追いつかなくなることによる。

（4）ひずみ速度が $5 \times 10^{-2} \mathrm{~s}^{-1}$ を超えると局部伸びが増加 するのは，局部変形域において粒界すべりが発生すること によって，くびれの拡散性が高まることによる。

\section{文献}

1）阿部光延，小甲康二，新井信一，速水哲博：日本金属学会誌，45 (1981), p.942

2）沢田清孝, 北原英樹, 板橋正章, 湯本久美, 河田幸三, 井形直弘 : 材料とプロセス， 4 (1990)，p.1890

3) M.F. Shi and D.J. Meuleman : Society of Automotive Engineers, Paper No. 920245 (1992)

4）大上哲郎，武智 弘，古野嘉邦：塑性と加工， 28 (1987), p.225

5 ）広瀬洋三, 須藤忠三: 平成 2 年度塑性加工春季講演会論文集, (1990), p. 425

6 ）鈴木 弘：塑性加工（改訂版），(1985)，p.64 [裳華房]

7 ) A.S. Keh, W.A. Spitzeg and Y. Nakada : Phil. Mag., 23 (1971), p. 829

8 ）水沼 晋，山口重裕，阿部光延，速水哲博：鉄 と鋼，66（1980）, p. 224

9 ) 鹿内伸夫, 田川寿俊，田中淳一：鉄 と鋼， 73 (1987), p.706 